\title{
Self-Healing sebagai Metode Pengendalian Emosi
}

\author{
M. Anis Bachtiar ${ }^{1}$, Aun Falestien Faletehan ${ }^{2 *}$ \\ UIN Sunan Ampel Surabaya \\ anis.bachtiar@uinsby.ac.id, aunfalestien@uinsby.ac.id \\ *Correspondence
}

Article Information:

Received 20 September 2020

Revised 24 April 2021

Accepted 19 May 2021

Keywords:

Emotion management; Pencak silat; Self-healing; Spiritual development

Kata Kunci:

Pengendalian emosi; Pengembangan spiritual; Pencak silat; self-healing

\section{Abstract}

The problems of stress and failure in emotion management among teenagers have always been a major concern among scholars and practitioners. Recent literature has been trying to find the best formula to help teenagers to control their emotions. This study aims to examine the influence of self-healing on teenagers' emotion management. Based on an experimentalquantitative approach including both pre-test and post-test designs, this study details how structured training and practice of self-healing may help individuals in managing their emotions. By taking a research setting in one of the theoretically selected educational institutions, this study periodically tested and observed 40 students as training participants. As a result, apart from demonstrating the uniqueness osf self-healing training which involves spiritual development processes (e.g., pembaiatan, religious learning) and physical exercise (e.g., pencak silat, relaxed breathing training), the findings also show that self-healing has a positive impact on students' ability to control their emotion.

Abstrak
Problematika stress dan kegagalan pengendalian emosi dikalangan remaja selalu menjadi perhatian utama dikalangan akademisi dan praktisi. Beberapa literatur mutakhir masih berusaha menemukan formula terbaik untuk membantu remaja dalam mengendalikan emosi. Studi ini bertujuan untuk menguji pengaruh self-healing terhadap kemampuan pengendalian emosi remaja. Dengan menggunakan pendekatan eksperimenkuantitatif berbasis desain pre-test dan post-test, studi ini menjelaskan bagaimana sebuah pelatihan dan praktek selfhealing terstruktur bisa membantu seseorang dalam mengendalikan emosi. Melalui pengambilan setting penelitian di salah satu lembaga pendidikan yang sudah terseleksi secara teoritis, studi ini menguji dan mengobservasi 40 siswa sebagai partisipan pelatihan secara berkala. Hasilnya, selain mendemonstrasikan keunikan pelatihan self-healing yang melibatkan proses pengembangan spiritual (misal: pembaiatan, pengajian) dan penguatan raga (misal: pencak silat, pelatihan pernafasan), temuan riset juga menunjukkan bahwa pelatihan self-healing berdampak positif terhadap kemampuan siswa dalam mengendalikan emosinya. 


\section{PENDAHULUAN}

Kalangan remaja terutama bagi mereka yang masih berada di bangku sekolah, termasuk kelompok yang rentan mengalami stress (Ben Mabrouk dkk., 2017; Elliott, 2014; Jacob dkk., 2013; van Berkel \& Reeves, 2017). Di samping masih berada dalam masa pencarian jati diri yang terkadang membingungkan, mereka juga dituntut untuk bisa berhasil dalam hal akademik dan juga kehidupan sosial (Franco dkk., 2019; Koudela-Hamila dkk., 2020). Banyak dari anak muda yang kemudian gagal dalam mengendalikan emosi akibat tidak bisa membagi waktu antara urusan akademik, kebutuhan sosial, dan keperluan relaksasi (Eltink dkk., 2018; Fogaca, 2021; Lin dkk., 2020), sehingga memicu emosi negatif atau marah yang pada akhirnya memicu penyimpangan buruk di kalangan remaja (Das \& Avci, 2015). Secara khusus untuk siswa, penyebab stress biasanya muncul dari faktor terkait akademik, dinamika aktivitas kelompok, relasi sosial, aspek interpersonal, faktor dorongan dan tuntutan personal, dan proses pembelajaran di kelas (Melaku dkk., 2015).

Melihat peliknya problem pengendalian emosi dikalangan remaja, sejumlah peneliti mengarahkan perlunya manajemen emosi untuk mengurangi tingkatan stress sekaligus bermanfaat untuk membenahi kinerja akademik siswa dan membantu mereka dalam membangun relasi sosial yang positif di lingkungan sekitar (Fogaca, 2021; Moore dkk., 2021). Pengendalian emosi, atau anger management, merupakan skill mereduksi amarah atau stress yang diperlukan semua individu (Kadiyono \& Anmarlina, 2016). Amarah adalah emosi yang normal dialami setiap orang (Ayebami \& Janet, 2017) dan mencakup banyak perasaan seperti takut, malu, bersalah, tidak berdaya dan lemah. Meskipun kemarahan adalah bagian penting dari fitrah manusia yang terkadang membantu untuk beradaptasi dan bertahan menghadapi tantangan hidup (Pilania dkk., 2015), kecenderungan marah yang tidak terkontrol akan berakibat pada perilaku negatif. Hal ini dikarenakan unsur-unsur emosi marah kebanyakan terdiri dari sifat-sifat negatif dan bisa terekspresikan dalam wujud kekerasan, melukai diri sendiri, dan agresi fisik ataupun verbal sehingga mengganggu orang lain (te Brinke dkk., 2021).

Oleh karenanya, setiap individu sangat penting untuk bisa mengelola emosi secara baik karena kemarahan dan emosi bukanlah sesuatu yang bisa dihilangkan sepenuhnya (Pilania dkk., 2015). Lebih rumit pula dalam mengelola amarah daripada menahan atau membiarkannya mengingat sifat amarah yang mudah naik dan turun; atau moody mengikuti alur situasi yang berkembang di sekitar (te Brinke dkk., 2021). Oleh karenanya, diperlukan banyak metode untuk bisa mengendalikan emosi secara efektif.

Self-healing merupakan salah satu metode yang cukup mendapatkan perhatian karena dianggap bisa membantu seseorang untuk mengendalikan emosi dan amarah (Chan dkk., 2013; Crane \& Ward, 2016). Self-healing secara harfiah mengandung makna penyembuhan diri, karena kata healing sendiri diartikan sebagai "a process of cure": suatu proses pengobatan/penyembuhan. Self-healing dimaksudkan sebagai suatu proses pengobatan atau penyembuhan yang dilakukan sendiri melalui proses 
keyakinannya sendiri dan juga didukung oleh lingkungan dan faktor eksternal penunjang (Crane \& Ward, 2016). Self-healing sangat berkaitan dengan keyakinan karena konteks self atau diri menjadi elemen yang penting dalam memotivasi kepercayaan diri seseorang. Selain itu, self-healing juga berkaitan dengan komunikasi intrapersonal karena adanya proses dialog internal yang terjadi di dalam ruang self itu sendiri. Self sendiri dapat dibatasi sebagai "individu known to individual" yang di dalamnya memuat sejumlah komponen dan proses yang dapat diidentifikasi seperti kognisi, persepsi, memori, rasa/hasrat, motivasi, kesadaran, dan hati nurani (Beck dkk., 2002).

Penerapan self-healing bisa dalam bentuk praktek individu atau melalui bimbingan secara terstruktur seperti pelatihan (Hongo dkk., 2018). Dalam bentuk yang terakhir tersebut, self-healing bisa dimodifikasi secara komprehensif oleh seorang trainer dan kemudian diajarkan kepada individu-individu lain. Pengembangan pelatihan self-healing bisa bervariasi. Beberapa praktek terkadang memasukkan elemen-elemen pengaya seperti sisi spiritual, pembersihan jiwa, gerak fisik, bela diri, dan sebagainya. Dalam konteks Indonesia, tradisi pencak silat menjadi salah satu budaya dan seni bela diri yang memiliki unsur-unsur self-healing dalam proses pelatihannya. Literatur saat ini belum begitu banyak mengkaji peranan pelatihan self-healing dalam membantu pengendalian emosi di kalangan remaja, terutama melalui kombinasi pelatihan psikis dan fisik secara bersamaan. Oleh karena itu, dengan mengambil setting penelitian pelatihan pencak silat yang dikelola oleh Ikatan Pencak Silat Nahdlatul Ulama (IPSNU) Pagar Nusa di Jombang, riset ini mengkaji pengaruh pelatihan self-healing (dengan kombinasi pelatihan psikis dan fisik) terhadap kemampuan siswa dalam mengontrol emosi. Hipotesis studi ini menunjukkan bahwa pelatihan self-healing memiliki dampak positif terhadap kemampuan siswa dalam mengendalikan emosi.

\section{METODE}

Mengingat pentingnya upaya pengendalian emosi dikalangan remaja melalui pelatihan self-healing, studi ini didesain untuk mengamati lebih jauh bagaimana dampak pelatihan self-healing terhadap kemampuan remaja dalam mengendalikan emosi. Dengan mengambil setting lokasi di lembaga pendidikan di Jombang, Jawa Timur, studi ini mengambil pendekatan kuantitatif eksperimental untuk menguji proposisi dan keterkaitan pelatihan self-healing terhadap kemampuan remaja dalam mengendalikan emosi.

Studi ini menggunakan paradigma kuantitatif dengan pendekatan eksperimen pada kelompok tunggal yang menerapkan desain tempo dua tahap: pra test dan post test. Penelitian kuasi eksperimen amat bermanfaat untuk menentukan efek variabel bebas terhadap variabel tergantung, di mana pengaruh variabel-variabel lain dieliminasi sedemikian rupa secara terkontrol (Faisal, 1999). Rancangan kuasi eksperimen dibangun atas dasar materi ekuivalen pada kelompok tunggal. 
Data riset berasal dari filter atas beberapa sekolah-sekolah Ma'arif NU di kabupaten Jombang, Jawa Timur yang aktif melakukan pelatihan Pagar Nusa dengan muatan pembelajaran dan praktek self-healing. Dari jumlah populasi sebanyak 426 sekolah, ditemukan 12 sekolah yang aktif mengikuti pelatihan. Kemudian peneliti memilih satu sekolah, yakni SMPNU Mojoagung, sebagai sampel utama dengan dasar tingkat intensitas dalam pelaksanaan pelatihan self-healing. Jumlah siswa yang aktif mengikuti latihan sebanyak 40 siswa. Dalam konteks ini, peneliti menggunakan rancangan sampel non-probabilitas dengan teknik pengambilan purposive sampling, yaitu sampel ditetapkan secara sengaja oleh peneliti dengan didasarkan pada kriteria dan pertimbangan tertentu. Penentuan sampel berdasarkan kriteria-kriteria sebagai berikut: (1) kontinuitas dalam pelatihan; (2) usia peserta pelatihan hampir setara; (3) tingkat pendidikan; dan (4) tidak mengikuti kegiatan organisasi bela diri lain.

Di fase awal dalam memahami nuansa dan profil setting penelitian, peneliti melakukan wawancara mendalam dengan jajaran pengurus, dewan guru, pelatih dan siswa. Selanjutnya, dalam proses penggalian data, peneliti juga mengamati secara langsung terhadap kegiatan-kegiatan yang diadakan oleh sekolah penyelenggara pelatihan, yang meliputi teknik-teknik pelatihan atau pemberian materi, dan juga reaksi dan praktek dari para siswa di waktu sebelum dan setelah mengikuti pelatihan.

Namun pada dasarnya, riset ini bertumpu pada data angket yang disebarkan kepada 40 siswa peserta pelatihan sebagai responden. Angket menggunakan tipe pertanyaan pilihan berganda. Jawaban sudah disediakan dalam angket dan para responden tinggal memilih salah satu jawaban yang sesuai dengan opininya. Responden cukup memberikan tanda $\mathrm{X}$ pada jawaban yang sesuai dengan preferensi mereka. Pilihan jawaban terdiri dari empat pilihan: sering/sangat, kadang- kadang, jarang/kurang, dan tidak pernah. Isi angket menjelaskan sembilan indikator untuk mengetahui perubahan emosi: (1) merasa jengkel; (2) merasa gelisah; (3) merasa frustasi karena harus menunggu sesuatu; (4) selalu berfikir negatif; (5) merasa sulit berkonsentrasi; (6) merasa marah; (7) merasa sulit untuk mengambil keputusan; (8) merasa kehilangan rasa humor; dan (9) mengalami ledakan emosi. Indikator ini merupakan adaptasi dari Depression Anxiety Stress Scales (DASS) yang dirancang untuk mengukur besarnya tiga keadaan emosi yang bersifat negatif: depresi, kecemasan, dan stres (Crawford \& Henry, 2003).

Proses penggalian data riset ini mencakup empat fase. Fase pertama meliputi seleksi terhadap populasi sekolah yang mengikuti pelatihan Pagar Nusa dengan materi self-healing untuk dijadikan sampel penelitian. Kemudian, fase kedua adalah penyebaran angket sebagai masa pelaksanaan pre-test. Fase ketiga adalah pemberian treatment eksperimental selama delapan minggu dalam bentuk praktek penerapan selfhealing, yang kemudian juga dilanjutkan dengan pelaksanaan post-test berupa pertanyaan dalam bentuk angket lanjutan. Dalam fase treatment eksperimental ini, peserta pelatihan diberi materi bela diri fisik dan psikis bermuatan self-healing yang 
menjadi ciri khas pelatihan Pagar Nusa. Pada akhirnya, fase keempat riset ini adalah analisis atas data yang sudah diperoleh dari pre-test dan post-test. Karena penelitian ini menggunakan paradigma kuantitatif, maka analisis yang digunakan dalam penelitian ini menggunakan analisis data kuantitatif dengan rumus (Sudijono, 2012) sebagaimana berikut:

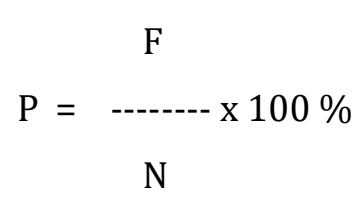

Keterangan :

$P$ : Persentase

F : Frekuensi yang dicari

$N$ : Jumlah responden

\section{PAPARAN HASIL}

Pelatihan self-healing dalam setting penelitian ini merupakan pengembangan dari pelatihan pencak silat Pagar Nusa yang menjadi tradisi dan program pembinaan siswa Lembaga Ma'arif Nahdlatul Ulama (NU) Jombang yang bekerjasama dengan Ikatan Pencak Silat Nahdlatul Ulama (IPSNU) Pagar Nusa. IPSNU Pagar Nusa adalah satu-satunya wadah yang sah bagi organisasi pencak silat di lingkungan NU berdasarkan keputusan Muktamar. Organisasi ini berstatus lembaga milik NU yang penyelenggaraan dan pertanggungjawabannya sama seperti lembaga-lembaga NU lainnya. Status resmi kelembagaan inilah yang menjadikan seni pelatihan pencak silat Pagar Nusa wajib dilestarikan dan dikembangkan oleh seluruh warga NU. Segala kegiatan yang berhubungan dengan pencak silat seperti pelatihan fisik hingga mental, atau muatan nilai-nilai pendidikan hingga sistem pengamanan, merupakan bidang garapan lembaga ini.

Materi pelatihan seni bela diri pencak silat Pagar Nusa meliputi beberapa tahapan seperti wawancara, pembaiatan, pengajian, pelatihan pernafasan, dan praktek bela diri atau pencak silat. Berbagai tahapan tersebut diberikan secara holistik dan berkesinambungan. Wawancara adalah tahap awal untuk pengenalan lebih dalam antara instruktur pelatih dengan siswa. Kemudian, pembaiatan adalah proses mengajak peserta untuk mendatangi makam dan kemudian dilakukan perjanjian dan sumpah agar mereka tidak lagi melanggar lima dosa (molimo) yaitu mencuri, berzina, mencandu narkoba, meminum minuman memabukkan, dan bermain judi. Jika melanggar, mereka siap akan menerima hukuman dari organisasi dan juga sanksi transendental dari Allah. Setelah dibaiat, peserta akan mendapatkan pengajian atau pembelajaran agama secara rutin. Proses ini biasa disebut dengan pemberian tausiyah yakni pembelajaran tentang akhlak yang terpuji. Beriringan dengan proses tersebut, peserta juga rutin mendapatkan pelatihan fisik yakni berupa praktek bela diri atau pencak silat dan juga latihan olah pernafasan. 
Dalam setting penelitian tersebut, studi ini dilakukan untuk mengetahui pengaruh pelatihan dan praktek self-healing terhadap kemampuan siswa dalam mengendalikan emosinya. Setelah dilakukan pre-test dan post-test, hasil riset menunjukkan beberapa temuan terkait sembilan indikator.

Perubahan kemampuan siswa dalam menghadapi kebiasaan diri yang selalu merasa jengkel terhadap sesuatu (kondisi sebelum dan setelah test).

Tabel 1. Merasa jengkel (pre-test dan post-test)

\begin{tabular}{lccccc}
\hline \multicolumn{1}{c}{ Alternatif Jawaban } & \multirow{2}{*}{ N } & \multicolumn{2}{c}{ Pre-test } & \multicolumn{2}{c}{ Post-test } \\
& & F & \% & F & \% \\
\hline A. Sering jengkel & & 35 & 87,5 & & \\
B. Jengkel & 5 & 12,5 & 35 & 87,5 \\
C. Agak jengkel & & & & 5 & 12,5 \\
\begin{tabular}{l} 
D. Tidak jengkel \\
\multicolumn{1}{c}{ Jumlah }
\end{tabular} & 40 & 40 & 100 & 40 & 100 \\
\hline
\end{tabular}

Tabel 1 menjelaskan kondisi awal peserta sebelum dilakukan pelatihan dan praktek self-healing yang menggambarkan bahwa sebagian besar responden $(87,5 \%)$ menyatakan bahwa mereka sering mengalami perasaan jengkel. Sementara itu, terdapat $12,5 \%$ responden yang menyatakan bahwa merasa jengkel tapi tidak seberapa sering. Kemudian setelah dilakukan pelatihan dan praktek self-healing, terdapat perubahan signifikan. Sebagian besar responden $(87,5 \%)$ menyatakan bahwa mereka mengalami perasaan jengkel, dan $12,5 \%$ responden menyatakan merasa agak jengkel tapi tidak sering. Sisi positifnya, tidak ada lagi responden yang merasa sering jengkel, seperti yang terjadi dalam fase pre-test yang tampak dalam tabel 1.

Perubahan kemampuan siswa dalam menghadapi kebiasaan diri yang selalu merasa gelisah ketika merespon sesuatu (kondisi sebelum dan setelah test).

Tabel 2. Merasa gelisah (pre-test dan post-test)

\begin{tabular}{lccccc}
\hline \multicolumn{1}{c}{ Alternatif Jawaban } & \multirow{2}{*}{ N } & Pre-test & \multicolumn{2}{c}{ Post-test } \\
& & & \% & F & \% \\
\hline A. Sangat gelisah & & 35 & 87,5 & & \\
B. Gelisah & & 5 & 12,5 & 35 & 87,5 \\
C. Jarang gelisah & & & & 5 & 12,5 \\
D. Tidak gelisah & & 40 & 100 & 40 & 100 \\
\multicolumn{1}{c}{ Jumlah } & 40 & &
\end{tabular}

Tabel 2 menjelaskan kondisi awal peserta sebelum dilakukan pelatihan dan praktek self-healing yang menggambarkan bahwa sebagian besar responden $(87,5 \%)$ menyatakan bahwa mereka merasa gelisah sementara hanya $12,5 \%$ responden yang menyatakan bahwa mereka jarang merasa gelisah. Kemudian setelah dilakukan pelatihan dan praktek self-healing, terdapat perubahan signifikan. Sebagian besar responden (87,5\%) menyatakan bahwa merasa jarang gelisah dan bahkan 12,5\% responden menyatakan bahwa mereka tidak lagi merasa gelisah. Sisi positifnya, tidak ada lagi responden yang merasa gelisah, seperti yang terjadi dalam fase pre-test yang tampak dalam tabel 2. 
Perubahan kemampuan siswa dalam menghadapi kebiasaan diri yang selalu merasa frustasi manakala harus menunggu sesuatu (kondisi sebelum dan setelah test).

Tabel 3. Merasa frustasi karena harus menunggu sesuatu (pre-test dan post-test)

\begin{tabular}{|c|c|c|c|c|c|}
\hline \multirow{2}{*}{ Alternatif Jawaban } & \multirow{2}{*}{$\mathbf{N}$} & \multicolumn{2}{|c|}{ Pre-test } & \multicolumn{2}{|c|}{ Post-test } \\
\hline & & $\mathbf{F}$ & $\%$ & $\mathbf{F}$ & $\%$ \\
\hline A. Sangat frustasi & & & & & \\
\hline B. Frustasi & & 35 & 87,5 & 10 & 25 \\
\hline C. Jarang frustasi & & 5 & 12,5 & 15 & 37,5 \\
\hline D. Tidak frustasi & & & & 15 & 37.5 \\
\hline Jumlah & 40 & 40 & 100 & 40 & 100 \\
\hline
\end{tabular}

Tabel 3 menjelaskan kondisi awal peserta sebelum dilakukan pelatihan dan praktek self-healing yang menggambarkan bahwa sebagian besar responden $(87,5 \%)$ merasa frustasi manakala harus menunggu sesuatu dan sebagian kecil responden $(12,5 \%)$ menyatakan bahwa mereka jarang mengalami frustasi. Kemudian setelah dilakukan pelatihan dan praktek self-healing, terdapat perubahan yang cukup signifikan. Hanya $25 \%$ responden yang menyatakan merasa frustasi, 37,5\% responden menyatakan jarang mengalami frustasi, dan 37,5\% responden menyatakan tidak lagi merasa frustasi ketika harus menunggu sesuatu. Sisi positifnya adalah adanya penurunan secara signifikan atas jumlah responden yang merasa frustasi ketika di fase pre-test.

Perubahan kemampuan siswa dalam menghadapi kebiasaan diri yang selalu berfikir negatif (kondisi sebelum dan setelah test).

Tabel 4. Selalu berfikir negatif (pre-test dan post-test)

\begin{tabular}{|c|c|c|c|c|c|}
\hline \multirow[b]{2}{*}{ Alternatif Jawaban } & \multirow[b]{2}{*}{$\mathbf{N}$} & \multicolumn{2}{|c|}{ Pre-test } & \multicolumn{2}{|c|}{ Post-test } \\
\hline & & $\mathbf{F}$ & $\%$ & $\mathbf{F}$ & $\%$ \\
\hline A. Sangat berfikir negatif & & 35 & 87,5 & 15 & 37,5 \\
\hline B. Berfikir negatif & & 5 & 12,5 & 10 & 25 \\
\hline C. Jarang berfikir negatif & & & & 10 & 25 \\
\hline D. Tidak berfikir negatif & & & & 5 & 12.5 \\
\hline Jumlah & 40 & 40 & 100 & 40 & 100 \\
\hline
\end{tabular}

Tabel 4 menjelaskan kondisi awal peserta sebelum dilakukan pelatihan dan praktek self-healing yang menggambarkan bahwa sebagian besar responden $(87,5 \%)$ menyatakan bahwa mereka sering berfikir negatif dan hanya $12,5 \%$ responden menyatakan berfikir negatif. Kemudian setelah dilakukan pelatihan dan praktek selfhealing, terdapat perubahan yang cukup signifikan. 37,5\% responden menyatakan bahwa mereka sering berfikir negatif, 25\% responden menyatakan bahwa pernah berfikir negatif, 25\% responden menyatakan jarang berfikir negatif, dan sisi positifnya, terdapat $20 \%$ responden yang menyatakan bahwa mereka tidak lagi pernah berfikir negatif.

Perubahan kemampuan siswa dalam menghadapi kebiasaan diri yang merasa sulit berkonsentrasi (kondisi sebelum dan setelah test). 
Tabel 5. Merasa sulit berkonsentrasi (pre-test dan post-test)

\begin{tabular}{lccccc}
\multicolumn{1}{c}{ Alternatif Jawaban } & \multirow{2}{c}{ Pre-test } & \multicolumn{2}{c}{ Post-test } \\
\hline A. Sangat merasa sulit berkonsentrasi & & F & \% & F & \% \\
B. Merasa sulit berkonsentrasi & & & & \\
C. Agak merasa sulit berkonsentrasi & & 35 & 87,5 & 20 & 50 \\
D. Tidak merasa sulit berkonsentrasi & & 5 & 12,5 & 20 & 50 \\
$\quad$ Jumlah & 40 & 40 & 100 & 40 & 100 \\
\hline
\end{tabular}

Tabel 5 menjelaskan kondisi awal peserta sebelum dilakukan pelatihan dan praktek self-healing yang menggambarkan bahwa sebagian besar responden $(87,5 \%)$ menyatakan bahwa mereka merasa agak sulit berkonsentrasi dan sebagian kecil responden $(22,5 \%)$ menyatakan bahwa mereka agak sulit berkonsentrasi. Kemudian setelah dilakukan pelatihan dan praktek self-healing, terdapat perubahan yang signifikan. 50\% responden menyatakan agak merasa sulit berkonsentrasi dan 50\% responden juga menyatakan bahwa mereka tidak lagi merasa sulit untuk berkonsentrasi.

Perubahan kemampuan siswa dalam menghadapi kebiasaan diri yang merasa mudah marah (kondisi sebelum dan setelah test).

Tabel 6. Merasa marah (pre-test dan post-test)

\begin{tabular}{lccccc}
\hline \multicolumn{1}{c}{ Alternatif Jawaban } & N & \multicolumn{2}{c}{ Pre-test } & \multicolumn{2}{c}{ Post-test } \\
& & F & \% & F & \% \\
\hline A. Sangat merasa marah & & & & & \\
B. Merasa marah & & 10 & 25 & & \\
C. Agak merasa marah & & 25 & 62,5 & 35 & 87,5 \\
D. Tidak merasa marah & 5 & 12,5 & 5 & 12,5 \\
$\quad$ Jumlah & 40 & 40 & 100 & 40 & 100 \\
\hline
\end{tabular}

Tabel 6 menjelaskan kondisi awal peserta sebelum dilakukan pelatihan dan praktek self-healing yang menggambarkan bahwa $25 \%$ responden menyatakan mudah merasa marah, $62,5 \%$ responden menyatakan merasa agak mudah marah, dan hanya $12,5 \%$ responden menyatakan bahwa meraka tidak mudah merasa marah. Kemudian setelah dilakukan pelatihan dan praktek self-healing, terdapat perubahan yang cukup signifikan. Sebagian besar responden $(87,5 \%)$ menyatakan bahwa mereka merasa mudah agak marah dan sebagian kecil responden (12,5\%) menyatakan bahwa mereka tidak mudah merasa marah lagi.

Perubahan kemampuan siswa dalam menghadapi kebiasaan diri yang merasa mudah marah (kondisi sebelum dan setelah test).

Tabel 7. Merasa sulit untuk mengambil keputusan (pre-test dan post-test)

\begin{tabular}{lccccc}
\hline \multicolumn{1}{c}{ Alternatif Jawaban } & \multirow{2}{c}{ Pre-test } & \multicolumn{2}{c}{ Post-test } \\
& & F & \% & F & \% \\
\hline A. Sangat merasa sulit untuk mengambil & & & & \\
$\quad$ keputusan & 35 & 87,5 & 5 & 12.5 \\
B. Merasa sulit untuk mengambil keputusan & 5 & 22,5 & 25 & 62,5 \\
$\begin{array}{l}\text { C. Agak merasa sulit untuk mengambil keputusan } \\
\text { D. Tidak merasa sulit untuk mengambil keputusan }\end{array}$ & & & & 10 & 25 \\
$\quad$ Jumlah & 40 & 40 & 100 & 40 & 100 \\
\hline
\end{tabular}

48 | Journal An-Nafs: Kajian Penelitian Psikologi, Vol. 6 No. 1 Juni 2021 
Tabel 7 menjelaskan kondisi awal peserta sebelum dilakukan pelatihan dan praktek self-healing yang menggambarkan bahwa sebagian besar responden penelitian $(87,5 \%)$ menyatakan bahwa mereka merasa sulit dalam mengambil keputusan. Selain itu, sebagian kecil dari responden $(22,5 \%)$ juga menyatakan bahwa mereka agak merasa sulit dalam mengambil keputusan. Kemudian setelah dilakukan pelatihan dan praktek self-healing, $12,5 \%$ responden ternyata menyatakan merasa masih sulit mengambil keputusan. Kemudian sebagian besar responden $(62,5 \%)$ menyatakan merasa agak sulit mengambil keputusan dan $25 \%$ responden menyatakan bahwa mereka tidak merasa sulit dalam mengambil keputusan.

Perubahan kemampuan siswa dalam menghadapi kebiasaan diri yang merasa kehilangan rasa humor (kondisi sebelum dan setelah test).

Tabel 8. Merasa kehilangan rasa humor (pre-test dan post-test)

\begin{tabular}{lccccc}
\hline \multicolumn{1}{c}{ Alternatif Jawaban } & \multirow{2}{*}{ N } & \multicolumn{2}{c}{ Pre-test } & \multicolumn{2}{c}{ Post-test } \\
& & F & \% & F & \% \\
\hline A. Sering merasa kehilangan rasa humor & & 35 & 87,5 & 5 & 12,5 \\
B. Merasa kehilangan rasa humor & & 5 & 22,5 & 10 & 25 \\
C. Agak merasa kehilangan rasa humor & & & & 15 & 37,5 \\
$\begin{array}{l}\text { D. Tidak merasa kehilangan rasa humor } \\
\text { Jumlah }\end{array}$ & 40 & 40 & 100 & 40 & 100 \\
\hline
\end{tabular}

Tabel 8 menjelaskan kondisi awal peserta sebelum dilakukan pelatihan dan praktek self-healing yang menggambarkan bahwa sebagian besar responden $(87,5 \%)$ menyatakan sering merasa kehilangan rasa humor dan sebagian kecil responden $(22,5 \%)$ menyatakan bahwa mereka merasa kadang kehilangan rasa humor. Kemudian setelah dilakukan pelatihan dan praktek self-healing, terdapat perubahan yang cukup signifikan. $12,5 \%$ responden menyatakan sering merasa kehilangan rasa humor, $25 \%$ responden menyatakan merasa kehilangan rasa humor, $37,5 \%$ responden menyatakan agak merasa kehilangan rasa humor, dan $25 \%$ responden menyatakan tidak merasa kehilangan rasa humor. Dua kelompok responden terakhir adalah kelompok yang baru muncul setelah dilakukan post-test.

Perubahan kemampuan siswa dalam menghadapi kebiasaan diri yang mengalami ledakan emosi (kondisi sebelum dan setelah test).

Tabel 9. Mengalami ledakan emosi (pre-test dan post-test)

\begin{tabular}{lccccc}
\hline \multicolumn{1}{c}{ Alternatif Jawaban } & \multirow{2}{*}{ N } & \multicolumn{2}{c}{ Pre-test } & \multicolumn{2}{c}{ Post-test } \\
& & F & \% & F & \% \\
\hline A. Sering mengalami ledakan emosi & & 10 & 25 & 35 & 87,5 \\
B. Mengalami ledakan emosi & & 15 & 37,5 & 5 & 22,5 \\
$\begin{array}{l}\text { C. Kadang mengalami ledakan } \\
\quad \text { emosi }\end{array}$ & & 10 & 25 & & \\
$\begin{array}{l}\text { D. Tidak mengalami ledakan emosi } \\
\quad \text { Jumlah }\end{array}$ & 5 & 12,5 & & \\
$\quad$ & 40 & 40 & 100 & 40 & 100 \\
\hline
\end{tabular}


Tabel 9 menjelaskan kondisi awal peserta sebelum dilakukan pelatihan dan praktek self-healing yang menggambarkan bahwa $25 \%$ responden menyatakan sering mengalami ledakan emosi, 37,5\% responden menyatakan mengalami ledakan emosi, $25 \%$ responden menyatakan kadang mengalami ledakan emosi, dan 12,5\% responden menyatakan tidak mengalami ledakan emosi. Kemudian setelah dilakukan pelatihan dan praktek self-healing, terdapat perubahan yang cukup mengejutkan. Berdasarkan hasil penelitian sebagaimana pada tabel 18, sebagian besar $87,5 \%$ responden menyatakan bahwa mereka masih sering mengalami ledakan emosi dan 22,5\% responden menyatakan mengalami ledakan emosi.

\section{PEMBAHASAN}

Berdasarkan analisis angket di pre-test dan post-test, secara umum dapat dilihat bahwa memang ada pengaruh positif terhadap kondisi emosional para siswa antara masa sebelum dan masa sesudah mengikuti pelatihan self-healing. Hal ini juga berarti bahwa materi pelatihan self-healing mengandung unsur terapi yang berguna untuk mengelola emosi para siswa. Secara umum, kondisi emosi siswa setelah mengikuti pelatihan tidak sampai pada kondisi yang mengarah pada kecemasan atau depresi.

Temuan ini mendukung literatur berkembang yang menunjukkan adanya relasi kuat antara self-healing dan anger management. Sebagai misal, self-healing menjadi teknik prioritas dalam pengurangan stress dan menjadi alat manajemen emosi yang relevan bagi beberapa profesi khusus seperti tenaga medis dan mahasiswa keperawatan (Chan dkk., 2013; Crane \& Ward, 2016). Studi lain menguraikan percontohan intervensi self-healing pada kasus perawat dan juga pasien yang ternyata dapat membantu mereka dalam mengurangi stres dan kelelahan emosi (Hongo dkk., 2018).

Pada prinsipnya, artikel ini menekankan bahwa penyelesaian manajemen emosi tidak hanya menekankan pada aspek psikologis semata, meskipun stress bermuara dari sisi psikologis. Harus ada keseimbangan dengan mengobati stress melalui penyembuhan psikis dan juga penyegaran fisik. Hal ini mendukung salah satu hasil studi lain yang mengatakan bahwa konsep kesehatan adalah konstruk multidimensional yang meliputi kesehatan fisik, psikis, dan spiritual (Litalien dkk., 2021). Ketika banyak literatur yang menggambarkan bahwa perilaku spiritual lintas agama seperti sholat atau do'a (Achour dkk., 2019) dan meditasi adalah beberapa contoh terapi yang bisa membantu mereduksi stress yang dialami individu, studi ini juga mendukung temuan populer tersebut (Innes \& Selfe, 2014; Wongtongkam dkk., 2014). Bahkan studi ini mendemonstrasikan bahwa untuk metode pengendalian stress tidaklah hanya dengan terapi psikologis atau spiritual semata. Harus ada keseimbangan dengan turut menyertakan adanya penyegaran fisik, seperti melalui bela diri atau pencak silat yang sudah dimodifikasi dan diintegrasi dengan elemen spiritual, agar metode pengendalian emosi semakin bisa efektif. Hal ini dilihat dari konstruksi self-healing melalui praktik pencak silat Pagar Nusa yang mendeskripsikan dualitas keseimbangan antara pelatihan rohani dan jasmani.

50 | Journal An-Nafs: Kajian Penelitian Psikologi, Vol. 6 No. 1 Juni 2021 
Memang, salah satu elemen penting dalam pelatihan bela diri atau pencak silat adalah adanya praktek self-healing. Sebagai salah satu budaya penting di Indonesia, pencak silat merupakan keterampilan bela diri yang memiliki ajaran filosofis yang tinggi. Pencak silat akan berbahaya jika dimiliki dan dikuasai oleh orang yang tidak bertanggung jawab. Filosofi pencak silat pada hakikatnya adalah mencari kebenaran sejati yaitu pandangan hidup dan kebijaksanaan manusia dalam kaitannya dengan nilainilai budaya, kemasyarakatan, moral dan agama yang dihormati masyarakat Indonesia. Seorang pelaku silat dituntut memiliki sikap taqwa, tanggap, kuat, tanggon, dan trengginas. Pencak silat yang bernilai tinggi mengandung materi pendidikan untuk membentuk manusia yang berkarakter baik, berbudi pekerti yang luhur, mampu mengendalikan diri, serta mengamalkan berbagai perbuatan terpuji yang memberi implikasi positif bagi pembentukan diri dan pengembangan masyarakat (Ediyono \& Widodo, 2019). Pada intinya, seseorang yang menguasai pencak silat harusnya bisa mengontrol diri dan tidak mudah terbawa amarah.

Fungsi self-healing dalam pelatihan silat begitu nampak jelas seperti pengendalian diri, menjunjung tinggi nilai-nilai etika dan estetika dengan berpedoman pada moral dan agama. Hal inilah yang menjadi garansi bahwa pelatihan ketrampilan beladiri silat dapat membantu siswa untuk lebih dapat mengendalikan emosi dan mengembangkan sikap toleransi sesama manusia. Inilah yang memungkinkan seseorang terbebas dari berbagai tekanan psikologis dalam hidupnya. Salah satu studi menggambarkan bahwa amat memungkinkan bagi seseorang untuk melatih manajemen emosi dan kecemasan meskipun ia adalah seorang yang memiliki skill bela diri yang mumpuni seperti Taekwondo (Chang \& Hwang, 2017).

Salah satu temuan riset ini cukup mengejutkan manakala siswa peserta pelatihan self-healing tetap gagal mengendalikan ledakan emosi dan sedikit sulit dalam mengambil keputusan setelah mendapatkan treatment. Mereka memang berhasil dalam tujuh indikator lain seperti mengurangi rasa jengkel, marah, gelisah, frustasi, fikiran negatif, kesulitan konsentrasi, dan mudah mengekspresikan rasa humor. Beberapa studi memang menggambarkan bahwa ledakan emosi merupakan sesuatu yang sulit diprediksi dan cenderung menjadi dorongan internal yang bersifat instan dan moody (te Brinke dkk., 2021) dan terkadang setiap individu sesekali pasti merasakan pengalaman ledakan ini. Begitu pula dengan kaitan antara stress and pengambilan keputusan. Beberapa riset mengindikasikan bahwa stres dan beban tambahan pada sistem manusia, yang disebabkan oleh tugas memori kerja paralel, bisa mengganggu proses pengambilan keputusan yang sedang dilakukan individu (Gathmann dkk., 2014; Pabst dkk., 2013).

\section{SIMPULAN}

Studi yang menekankan pada data pre-test dan post-test dalam praktek selfhealing di pencak silat Pagar Nusa ini menghasilkan dua poin penting: 1). Self-healing adalah aktivitas terstruktur yang seimbang dalam hal melibatkan proses pengembangan 
spiritual (misal: pembaiatan, pengajian) dan penguatan raga (misal: pencak silat, pelatihan pernafasan. Berbagai tahapan tersebut diberikan secara holistik dan berkesinambungan. Pelaksanaan pelatihan ini juga menunjang adanya evaluasi atau ujian pada setiap tingkatan materi. Materi ujian adalah seputar isu-isu spiritual keagamaan dan praktik bela diri atau pencak silat. 2). Self-healing memiliki dampak positif terhadap kemampuan siswa dalam mengendalikan emosi. Selain indikator pada ledakan emosi dan kesulitan dalam pengambilan keputusan yang masih dialami peserta setelah post-test, mayoritas siswa menunjukkan indikasi perubahan positif karena bisa menghilangkan indikator-indikator emosi negatif lain seperti merasa jengkel, merasa gelisah, merasa frustasi karena harus menunggu sesuatu, selalu berfikir negatif, merasa sulit berkonsentrasi, merasa marah, dan merasa kehilangan rasa humor.

\section{DAFTAR PUSTAKA}

Achour, M., Binti Abdul Ghani Azmi, I., Bin Isahak, M., Mohd Nor, M. R., \& Mohd Yusoff, M. Y. Z. (2019). Job stress and nurses well-being: Prayer and age as moderators. Community Mental Health Journal, 55(7), 1226-1235. https://doi.org/10.1007/s10597-019-00410-y

Ayebami, T. V., \& Janet, K. (2017). Efficacy of anger management strategies for effective living among adolescents and youths. IFE PsychologIA, 25(1), 47-58.

Beck, A., Bennett, P., \& Wall, P. (2002). AS Communication Studies: The Essential Introduction. London: Routledge.

Ben Mabrouk, N., Bourgou, S., Staali, N., Hamza, M., Ben Hammouda, A., Charfi, F., \& Belhadj, A. (2017). Does gender matter? A comparative study of posttraumatic stress disorder among children and teenager. European Psychiatry, 41(Supplement), S431. https://doi.org/10.1016/j.eurpsy.2017.01.413

Chan, E. S., Koh, D., Teo, Y. C., Hj Tamin, R., Lim, A., \& Fredericks, S. (2013). Biochemical and psychometric evaluation of Self-Healing Qigong as a stress reduction tool among first year nursing and midwifery students. Complementary Therapies in Clinical Practice, 19(4), 179-183. https://doi.org/10.1016/j.ctcp.2013.08.001

Chang, D., \& Hwang, S. (2017). The development of anger management program based on acceptance and commitment therapy for youth taekwondo players. Journal of Exercise Rehabilitation, 13(2), 160-167. https://doi.org/10.12965/jer.1732882.441

Crane, P. J., \& Ward, S. F. (2016). Self-healing and self-care for nurses. AORN Journal, 104(5), 386-400. https://doi.org/10.1016/j.aorn.2016.09.007

Crawford, J. R., \& Henry, J. D. (2003). The Depression Anxiety Stress Scales (DASS): Normative data and latent structure in a large non-clinical sample. British Journal of Clinical Psychology, 42(2), 111-131. https://doi.org/10.1348/014466503321903544 
Das, G. Y., \& Avci, I. A. (2015). The effect of anger management levels and communication skills of Emergency Department staff on being exposed to violence. Medicinski Glasnik, 12(1), 99-104.

Ediyono, S., \& Widodo, S. T. (2019). Memahami makna seni dalam pencak silat. Panggung, 29(3), 299-313. https://doi.org/10.26742/panggung.v29i3.1014

Elliott, G. (2014). Are our kids really that angry? An empirical investigation into adolescent aggression in the South African context (1st ed. NV). Anchor Academic Publishing.

Eltink, E. M. A., Ten Hoeve, J., De Jongh, T., Van der Helm, G. H. P., Wissink, I. B., \& Stams, G. J. J. M. (2018). Stability and change of adolescents' aggressive behavior in residential youth care. Child \& Youth Care Forum: Journal of Research and Practice in Children's Services, 47(2), 199-217. https://doi.org/10.1007/s10566-017-9425-y

Faisal, S. (1999). Format-Format Penelitian Sosial. Bandung: Remaja Rosdakarya.

Fogaca, J. L. (2021). Combining mental health and performance interventions: Coping and social support for student-athletes. Journal of Applied Sport Psychology, 33(1), 4-19. https://doi.org/10.1080/10413200.2019.1648326

Franco, M., Hsiao, Y.-S., Gnilka, P. B., \& Ashby, J. S. (2019). Acculturative stress, social support, and career outcome expectations among international students. International Journal for Educational and Vocational Guidance, 19(2), 275291. https://doi.org/10.1007/s10775-018-9380-7

Gathmann, B., Schulte, F. P., Maderwald, S., Pawlikowski, M., Starcke, K., Schäfer, L. C., Schöler, T., Wolf, O. T., \& Brand, M. (2014). Stress and decision making: Neural correlates of the interaction between stress, executive functions, and decision making under risk. Experimental brain research, 232(3), 957-973. https://doi.org/10.1007/s00221-013-3808-6

Hongo, A., Hashimoto, R., Shibata, K., Miao, T., \& Suzuki, M. (2018). Studying how the Self-healing Method can offer new hope for stressed and fatigued caregivers. Impact, 2018(12), 87-89. https://doi.org/10.21820/23987073.2018.12.87

Innes, K. E., \& Selfe, T. K. (2014). Meditation as a therapeutic intervention for adults at risk for Alzheimer's disease-Potential benefits and underlying mechanisms. Frontiers in psychiatry TA - $\quad T T \quad-, \quad 5,40$. https://doi.org/10.3389/fpsyt.2014.00040

Jacob, T., EB, I., \& Raz, O. (2013). Stress among healthcare students-A cross disciplinary perspective. Physiotherapy theory and practice, 29(5), 401-412. https://doi.org/10.3109/09593985.2012.734011

Kadiyono, A. L., \& Anmarlina, F. (2016). Teknik Yoga sebagai intervensi dalam melakukan anger management pada wanita dewasa awal. Jurnal Intervensi $\begin{array}{llll}\text { Psikologi (JIP), } & \text { 8(2), }\end{array}$ https://doi.org/10.20885/intervensipsikologi.vol8.iss2.art3 
Koudela-Hamila, S., Smyth, J., Santangelo, P., \& Ebner-Priemer, U. (2020). Examination stress in academic students: A multimodal, real-time, real-life investigation of reported stress, social contact, blood pressure, and cortisol. Journal of American College Health, 1-12. https://doi.org/10.1080/07448481.2020.1784906

Lin, X.-J., Zhang, C.-Y., Yang, S., Hsu, M.-L., Cheng, H., Chen, J., \& Yu, H. (2020). Stress and its association with academic performance among dental undergraduate students in Fujian, China: A cross-sectional online questionnaire survey. BMC Medical Education, 20(1), 181. https://doi.org/10.1186/s12909020-02095-4

Litalien, M., Atari, D. O., \& Obasi, I. (2021). The influence of religiosity and spirituality on health in Canada: A systematic literature review. Journal of Religion and Health (In press). https://doi.org/10.1007/s10943-020-01148-8

Melaku, L., Mossie, A., \& Negash, A. (2015). Stress among medical students and its association with substance use and academic performance. Journal of Biomedical Education, 2015(3), 1-9. https://doi.org/10.1155/2015/149509

Moore, M. F., Montgomery, L., \& Cobbs, T. (2021). Increasing student success through in-class resilience education. Nurse Education in Practice, 50, 102948. https://doi.org/10.1016/j.nepr.2020.102948

Pabst, S., Schoofs, D., Pawlikowski, M., Brand, M., \& Wolf, O. T. (2013). Paradoxical effects of stress and an executive task on decisions under risk. Behavioral Neuroscience, 127(3), 369-379. https://doi.org/10.1037/a0032334

Pilania, V. M., Mehta, M., \& Sagar, R. (2015). Anger management. Dalam M. Mehta \& R. Sagar (Ed.), A Practical Approach to Cognitive Behaviour Therapy for Adolescents (hlm. 109-130). Springer India. https://doi.org/10.1007/978-81-3222241-5_6

Sudijono, A. (2012). Pengantar Statistik Pendidikan. Jakarta: Raja Grafindo Persada (Rajawali pers).

te Brinke, L. W., Schuiringa, H. D., \& Matthys, W. (2021). Emotion regulation and angry mood among adolescents with externalizing problems and intellectual disabilities. Research in Developmental Disabilities (In press), 109. https://doi.org/10.1016/j.ridd.2020.103833

van Berkel, K., \& Reeves, B. (2017). Stress among graduate students in relation to health behaviors. College Student Journal, 51(4), 498-510.

Wongtongkam, N., Ward, P. R., Day, A., \& Winefield, A. H. (2014). A trial of mindfulness meditation to reduce anger and violence in Thai youth. International Journal of Mental Health and Addiction, 12(2), 169-180. https://doi.org/10.1007/s11469-013-9463-0 